Proc. Estonian Acad. Sci. Eng., 2006, 12, 4, 445-454

\title{
Abrasive wear properties of metal matrix composites produced by hot isostatic pressing
}

\author{
Sanna Ala-Kleme ${ }^{\mathrm{a}}$, Päivi Kivikytö-Reponen ${ }^{\mathrm{b}}$, Jari Liimatainen ${ }^{\mathrm{b}}$, \\ Jussi Hellman ${ }^{\mathrm{b}}$ and Simo-Pekka Hannula, \\ a Laboratory of Material Science, Helsinki University of Technology, POB 6200, 02015 TKK, \\ Espoo, Finland; sanna.ala-kleme@tkk.fi \\ b Metso Powdermet Oy, POB 237, 33101 Tampere, Finland \\ c VTT Technical Research Centre of Finland, 02044 VTT, Espoo, Finland
}

Received 31 July 2006

\begin{abstract}
Steel matrix composites are an attractive choice for paper, pulp and mineral crushing industries because of their wear resistant properties. In this paper the abrasive wear properties of the tool steel matrix composites are studied. The rubber wheel abrasion tests were carried out using six different composites. The tool steel Ralloy ${ }^{\circledR}$ WR6 was used as matrix material in all composites. Typically there is about $20 \mathrm{vol} \% \mathrm{VC}$ in the matrix before the addition of the particle reinforcements. Reinforcements were either cemented carbides (WC-Co), cast tungsten carbides (WC) or niobium carbides $(\mathrm{NbC})$. All the composites were so-called double dispersion composites having two distinctive reinforcement types. Although the wear resistance of the composite materials has been found to increase with reinforcement additions in rock crushing environment with multimode wear conditions, the pure abrasion resistance of the composites, having up to $30 \%$ additional reinforcements, was found inferior to the matrix tool steel. Based on the observations it is suggested that in order to improve the abrasive wear resistance of the tool steels by adding hard particles, the matrix-particle interface should be strong enough to prevent the detachment of particles and the amount of particles should be high enough to compensate the accelerated wear of the matrix because of hard particle wear debris.
\end{abstract}

Key words: steel matrix composites, tool steel, cemented carbide, tungsten carbide, niobium carbide, abrasion, wear mechanisms.

\section{INTRODUCTION}

Metal matrix composites (MMC) consist of the metal matrix and reinforcement (typically 10-40 vol\%). The reinforcement materials are usually ceramics (e.g. TiC, $\mathrm{WC}, \mathrm{NbC}$ and $\mathrm{Al}_{2} \mathrm{O}_{3}$ ). The composite materials offer such property 
combinations and performance profiles, which are not available in any conventional engineering materials $\left[{ }^{1,2}\right]$.

The properties of metal matrix composites depend on the shape, size, properties, volume fraction and distribution of the reinforcement material, properties of the matrix materials and compatibility of the matrix and reinforcement. Material properties also depend on the manufacturing method and on the heat treatment. The matrix-reinforcement interface has a strong influence on the mechanical properties of hard phase containing material. The properties of the interface depend on physical and chemical properties of the matrix and hard particles, and on the reaction between these materials during consolidation and subsequent heat treatment $\left[^{2,3}\right]$. It has been reported that reaction layers, which are relatively thick (around $1 \mu \mathrm{m}$ ), weaken mechanical properties of the composites, while the layers thinner than $0.1 \mu \mathrm{m}$ might be beneficial $\left.{ }^{1}\right]$. Lou et al. $\left[^{2}\right]$ have investigated interactions between the tungsten carbide and the metal matrix. They have reported that the matrix alloys were intruded easily into WC particles and reacted with WC during manufacturing, because there was a great amount of primary microporosity in WC particles.

The hardness of the reinforcement should be higher than that of the abrasive for obtaining good abrasion resistance. Also the matrix hardness should be as high as possible. In addition, the interparticle spacing should be smaller than the abrasive size and the reinforcement particle size should be bigger than the abrasive size $\left[{ }^{4,5}\right]$. The distribution of the reinforcement in the matrix depends also on the powder grains size. Relatively fine reinforcement would tend to surround the matrix powder grains like satellites, forming a brittle net-like structure $\left[{ }^{3}\right]$. The net-like structure may improve the abrasion resistance of the composites, because it reduces interparticle spacing $\left[{ }^{1}\right]$. The abrasion wear resistance of the composites increases with the reinforcement volume fraction if the damage in the reinforcements, cracking or pull-out of the matrix, is negligible $\left.{ }^{4,6,7}\right]$.

Hot Isostatic Pressing (HIP) is a powder metallurgy process that is suitable for the fabrication of MMCs. In the HIP process, a wide range of reinforcement volume fractions and size can be used and the distribution of the reinforcement obtained is quite homogeneous. This process results practically in a fully dense material. In addition, the HIP process allows near net shape production of complex forms, which will also significantly reduce the machining costs and delivery times of the components $\left[{ }^{1,8-10}\right]$. HIPed tool steel matrix composites have shown good performance in certain wear conditions, e.g. in Nordberg laboratory cone crusher $\left[{ }^{11}\right]$.

The aim of this study is to investigate the effect of the microstructure of metal matrix composites on abrasive wear performance. Especially the effect of reinforcement type and properties of the matrix-reinforcement interface on the abrasion resistance are of interest. 


\section{MATERIALS AND TEST PROCEDURES}

Six different steel-based composites were studied. In all composites the tool steel Ralloy ${ }^{\circledR}$ WR6 was used as the matrix material. The chemical composition of Ralloy ${ }^{\circledR}$ WR6 is $2.9 \% \mathrm{C}, 5.25 \% \mathrm{Cr}, 11.5 \% \mathrm{~V}, 1.3 \% \mathrm{Mo},<1 \% \mathrm{Mn},<1 \% \mathrm{Si}$, $<0.03 \% \mathrm{P},<0.03 \% \mathrm{~S}$ and remainder Fe. Typically there is about $20 \mathrm{vol} \%$ vanadium carbide (VC) in the matrix before the addition of the particle reinforcements. Additional reinforcements were recycled cemented carbides (WC-10Co), tungsten carbides or niobium carbides. Reinforcement content was varied between 17 and $30 \mathrm{vol} \%$ and the particle size between $200-500 \mu \mathrm{m}$. The particle size of the matrix tool steel powder was $350 \mu \mathrm{m}$. The composites were manufactured by hot isostatic pressing. The HIP processing was carried out at a temperature of $1180^{\circ} \mathrm{C}$ and at a pressure of $100 \mathrm{MPa}$ for three hours. After compaction Ralloy ${ }^{\circledR}$ WR6 matrix composites were austenitized at $1080^{\circ} \mathrm{C}$ for $2 \mathrm{~h}$, followed by a forced air cooling and a subsequent $2+2 \mathrm{~h}$ double tempering at $570^{\circ} \mathrm{C}$. The compositions of the studied composites are given in Table 1 .

The microstructures of the reinforcement particles are presented in Figs. 1a-f. There is a porous layer at the edge of the cemented carbide particles. Because these are recycled cemented carbides, the microstructure of the carbides vary. The carbide size within the cemented carbide reinforcement particle is about 2-6 $\mu \mathrm{m}$. The tungsten carbide particle is considerably more compact than the cemented carbide. In the niobium carbide, there is a quite dense outer layer, but the core of the particle is partly porous. The niobium carbide reinforcement consists of carbides whose size is about $1-6 \mu \mathrm{m}$.

The microstructures and interfaces were studied by optical and scanning electron microscopy (SEM). The chemical composition of the matrix-reinforcement interface was determined from energy dispersive X-ray spectrum (EDS analysis). The materials were tested for abrasion according to ASTM G 65-91 B, rubber wheel abrasion test. The used normal force was $130 \mathrm{~N}$ and total wear distance $1436 \mathrm{~m}$ (about $10 \mathrm{~min}$ ). Nilsiä quartz sand (SP Minerals) was used as abrasive. Sand flow was $470-490 \mathrm{~g} / \mathrm{min}$.

Table 1. Composition of the composites

\begin{tabular}{l|l|c|c}
\hline \multicolumn{1}{c|}{ Composite } & Reinforcement & $\begin{array}{c}\text { Particle size, } \\
\mu \mathrm{m}\end{array}$ & wt\% \\
\hline 17 vol\% WC/Co MMC & WC-Co & $200-400$ & 17 \\
24 vol\% WC/Co MMC & WC-Co & $200-400$ & 24 \\
20 vol\% WC MMC & WC & $250-425$ & 20 \\
30 vol\% WC MMC & WC & $250-425$ & 30 \\
20 vol\% NbC MMC & NbC & $250-500$ & 20 \\
30 vol\% NbC MMC & NbC & $250-500$ & 30
\end{tabular}




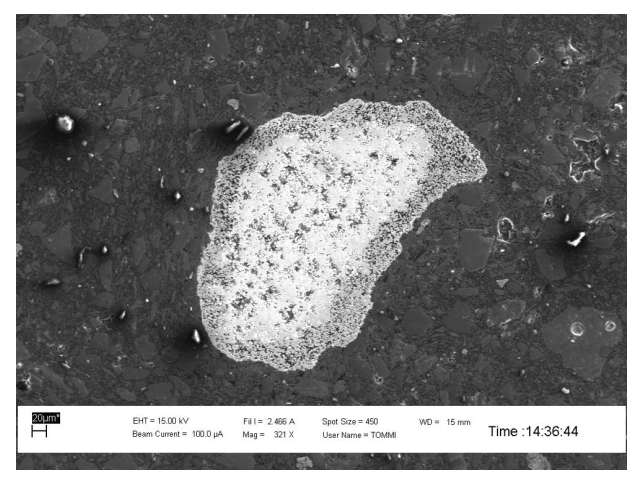

(a)

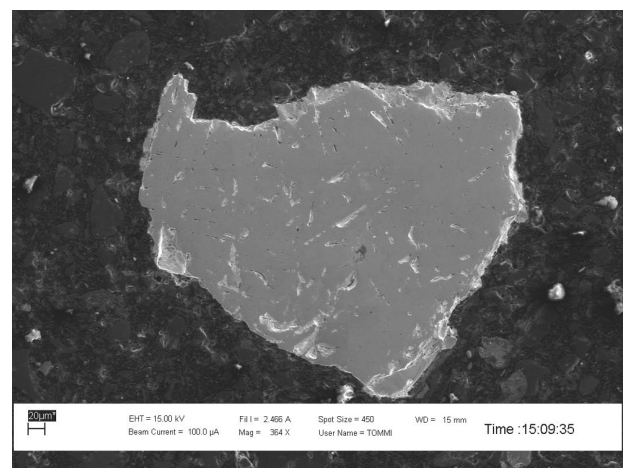

(c)

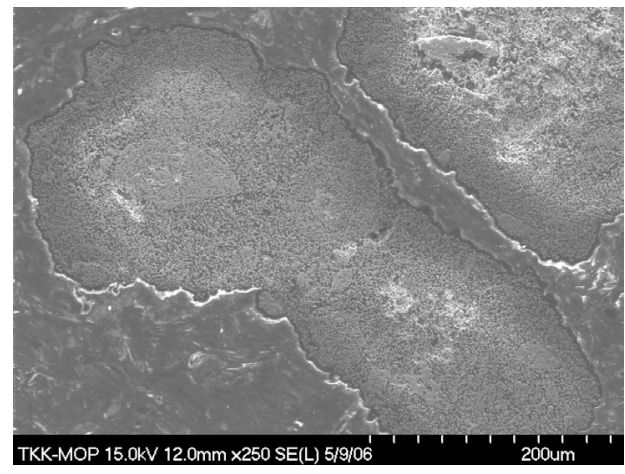

(e)

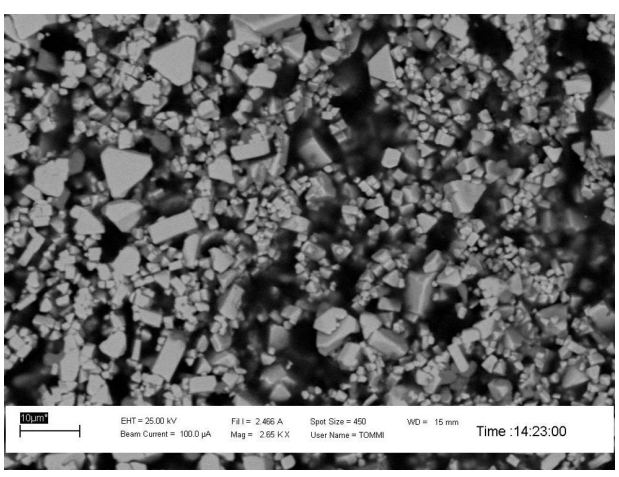

(b)

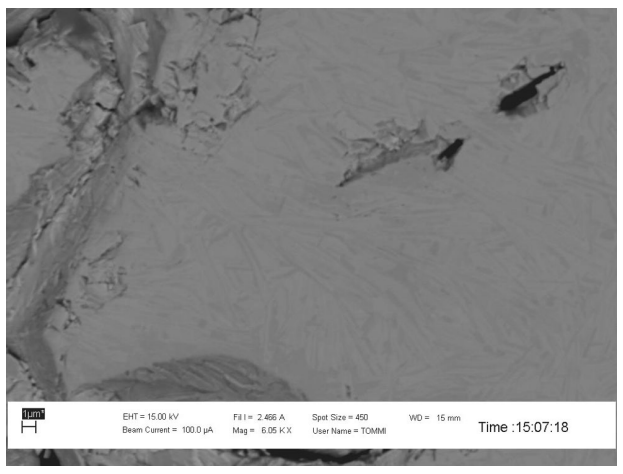

(d)

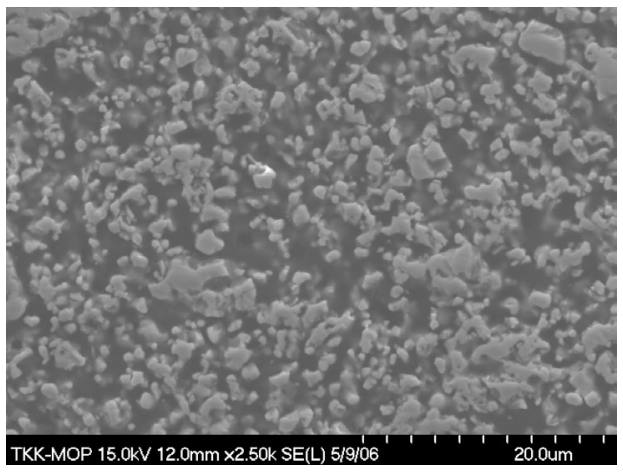

(f)

Fig. 1. Microstructure of WC-Co with magnification $321 \times($ a) and $2650 \times(b)$, WC $(364 \times(c)$ and $6050 \times(\mathrm{d}))$ and $\mathrm{NbC}(250 \times(\mathrm{e})$ and $2500 \times(\mathrm{f}))$. 


\section{RESULTS AND DISCUSSION}

\subsection{Microstructure of the composites}

The matrix of the composites consists of tempered martensite and of a fine dispersion of vanadium carbides $(<3 \mu \mathrm{m})$ buried in the tempered martensite matrix. The studied materials are therefore double-dispersion composites, which consist of two distinctly different areas of carbides. The total carbide content of the composites is thus much bigger than that calculated from the reinforcement content, because also the matrix includes carbides. Distribution of the reinforcements is quite uniform in $17 \mathrm{vol} \% \mathrm{WC}-\mathrm{Co} \mathrm{MMC}$ and $24 \mathrm{vol} \% \mathrm{WC}-\mathrm{Co} \mathrm{MMC}$ composites. Reinforcement-matrix interface zones are few micrometers thick (Fig. 2a). The thickness of the interface depends on the porous layer on the surface of the used cemented carbide particles (Fig. 1a), because it makes diffusion of the matrix elements to the cemented carbide particle easier. EDS analysis across the interface reveals that there is a diffusion of $\mathrm{Fe}, \mathrm{Cr}$ and $\mathrm{V}$ in the direction of the Co-WC particulate and of Co in the direction of the matrix.

In the WC reinforced composites the distribution of the reinforcements is inhomogeneous. Reinforcement-matrix interface zones are thick, up to $15 \mu \mathrm{m}$.

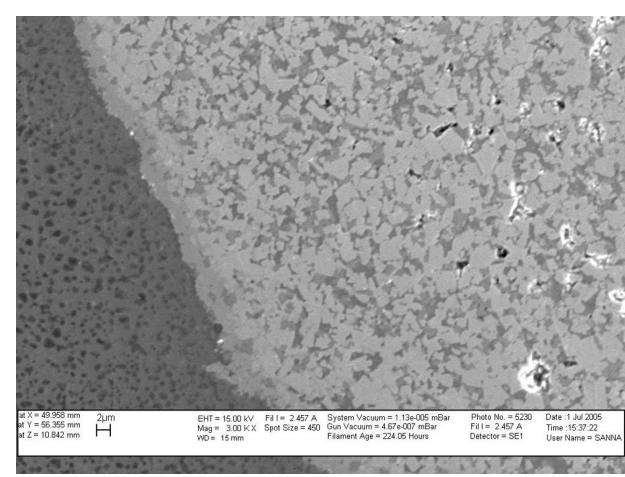

(a)

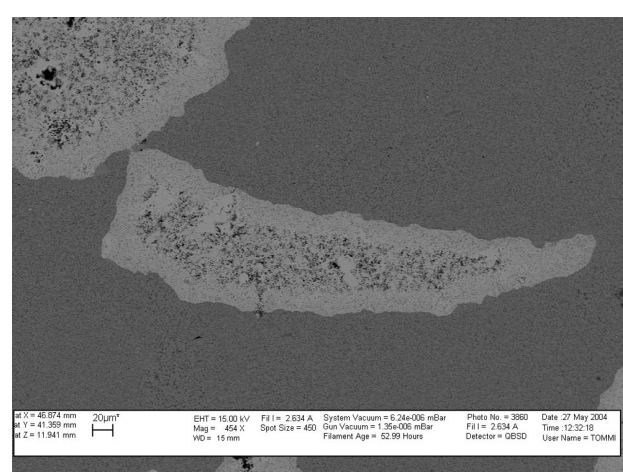

(c)

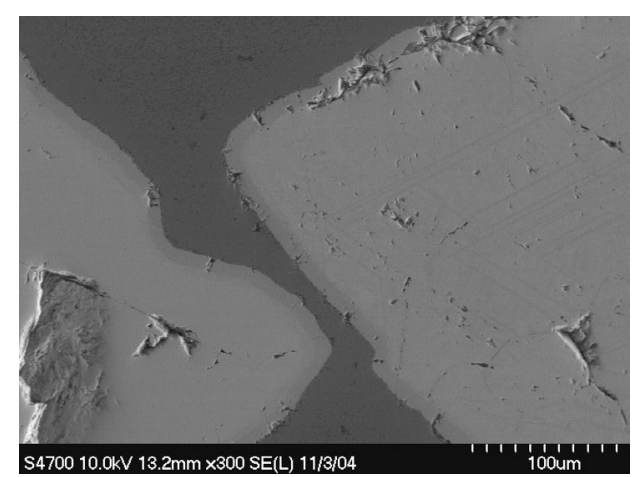

(b)

Fig. 2. Microstructures of the $17 \mathrm{vol} \% \mathrm{WC} / \mathrm{Co}$ MMC (a), 20 vol\% WC MMC (b) and 30 vol\% $\mathrm{NbC}$ MMC (c) composites. 
EDS analysis shows that some diffusion of $\mathrm{Fe}$ and $\mathrm{Cr}$ into the WC particles has occurred. Especially interface regions in these materials are very porous after polishing as shown in Fig. 2b. There are also some cracks at the interface areas and within the reinforcements. From this it can be inferred that the interface areas and the reinforcements are fragile.

The $20 \mathrm{vol} \% \mathrm{NbC}$ MMC and $30 \mathrm{vol} \% \mathrm{NbC}$ MMC composites have poor reinforcement distribution within the matrix. There is some coarsening and connecting of reinforcement particles. The niobium carbides and the matrix of the composites are both somewhat porous after polishing. Reinforcement-matrix interface is thick, about $15-30 \mu \mathrm{m}$, as can be seen in Fig. 2c. EDS analysis shows that some diffusion of $\mathrm{Fe}, \mathrm{Cr}$ and $\mathrm{V}$ into the $\mathrm{NbC}$ particle and slight diffusion of niobium into the matrix occurred. The interface is much more compact than the core of the reinforcement.

\subsection{Rubber wheel abrasion test}

The results of the abrasion tests are summarized in Fig. 3. Wear rate of HIPed Ralloy ${ }^{\circledR}$ WR6 is shown for reference. It seems that the addition of carbides into the tool steel deteriorates the abrasion resistance of the material although similar addition may improve the resistance in the case of some other modes of wear $\left[{ }^{11}\right]$. The reason for the observed behaviour, however, seemed to be different in each case. Therefore, wear modes of the various composites were studied by SEM. The matrix was Ralloy ${ }^{\circledR}$ WR6 in all studied composites and also the wear mechanisms of all matrices were found to be the same (microploughing and microcracking).

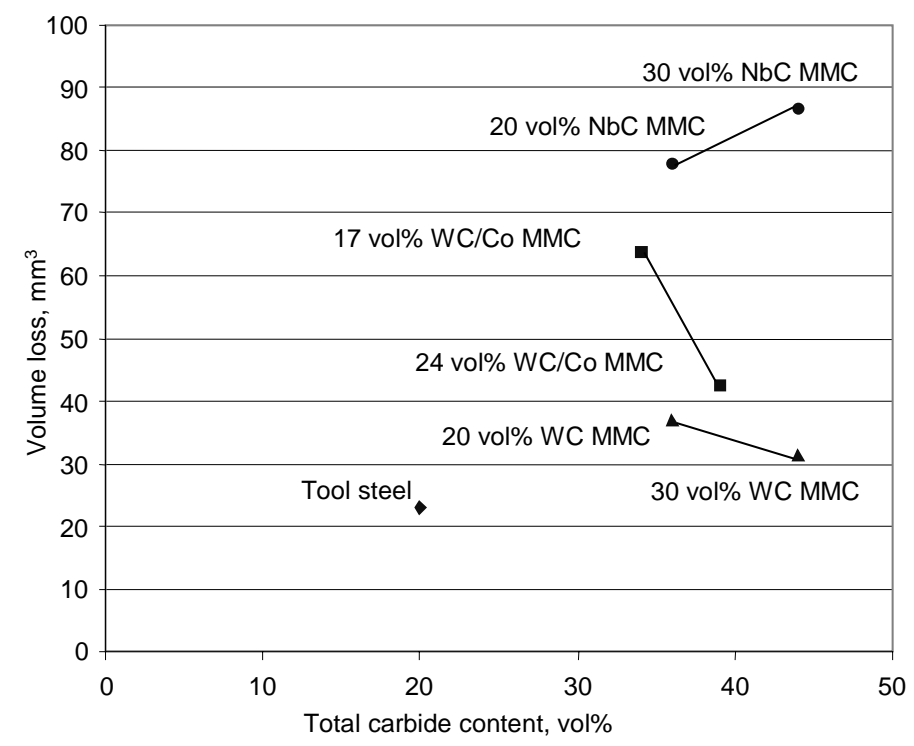

Fig. 3. Abrasive wear performance of the tool steel matrix composites. 
In the worn WC-Co reinforced composites there are several pores that are formed when WC/Co reinforcements are pulled out of the matrix (Fig. 4). This indicates that there are weak bonds between the matrix and $\mathrm{WC} / \mathrm{Co}$ reinforcement. The WC/Co reinforcements are worn also by microcracking. The agglomerates that were pulled out cause an increase in wear. This seems to be the main reason why the Ralloy ${ }^{\circledR}$ WR6 matrix has better wear resistance than the corresponding WC-Co reinforced composites. However, the wear resistance of the WC-Co reinforced composites is improved with increasing reinforcement content.

On the wear surface of the WC reinforced composites, reinforcements appear very clearly because the matrix has worn more than the reinforcement (Fig. 5a). Tungsten carbides are worn slightly by microcracking (Fig. 5b) but the reinforcements have not been pulled out of the matrix. This indicates that bonding between the matrix and reinforcement is good although the cracks in the micro-

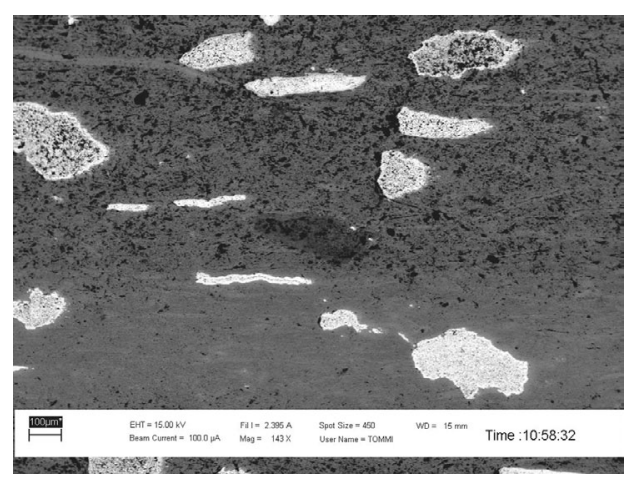

Fig. 4. The surface of the material $17 \mathrm{vol} \% \mathrm{WC} / \mathrm{Co} \mathrm{MMC}$ after the abrasive wear test. Wear direction is from the left to the right.

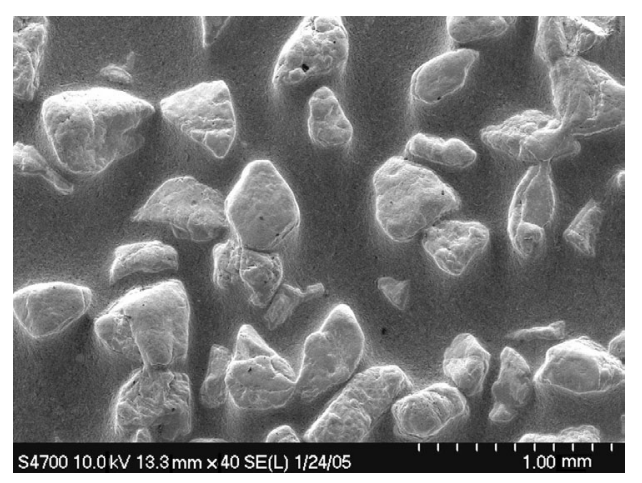

(a)

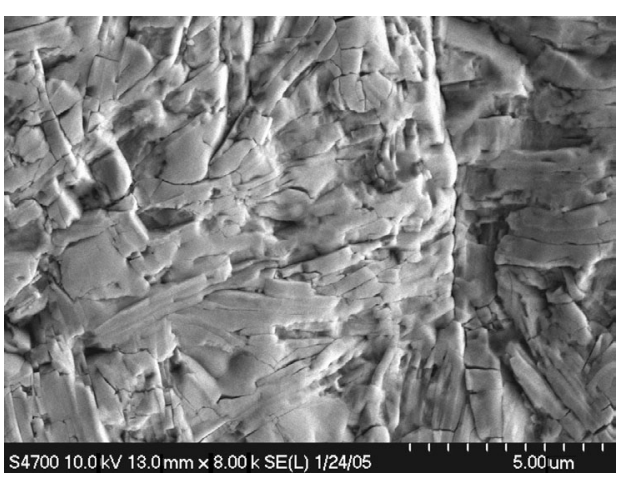

(b)

Fig. 5. Wear surface of the 30 vol\% WC MMC (a) and reinforcement (b). Wear direction is downwards. 


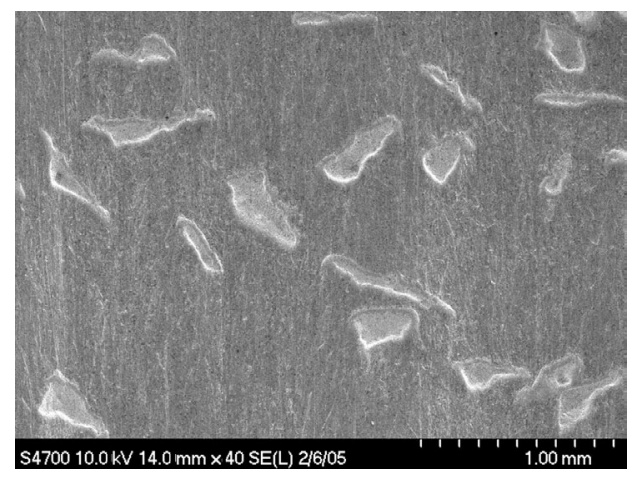

(a)

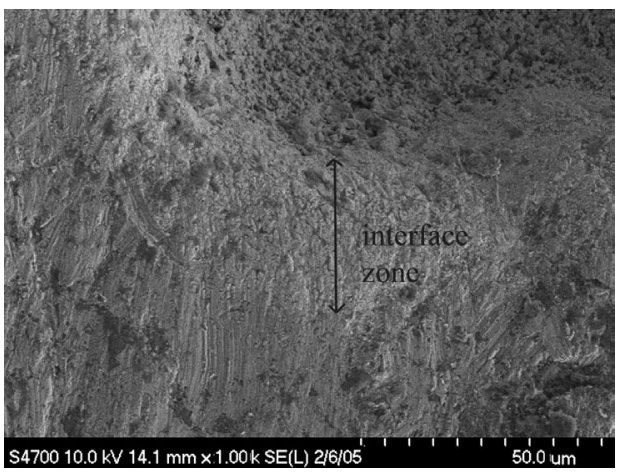

(b)

Fig. 6. Wear surface of the 20 vol\% NbC MMC (a) and interface (b). Wear direction is downwards.

structure may suggest the opposite. The abrasion resistance is much better than that of the WC-Co reinforced composites, but still inferior to that of the pure tool steel matrix. One reason for this behaviour is that the broken parts of the reinforcement act as an additional abrasive. Also in these composites, the wear resistance increased with the reinforcement content.

In the case of $\mathrm{NbC}$ reinforced composites, the interfaces are strong, but the $\mathrm{NbC}$ reinforcement itself is weak because of porosity. The interface zones are worn slightly, but the reinforcements are worn heavily by microcracking (Fig. 6). Therefore the wear resistance of $\mathrm{NbC}$ reinforced composites are much worse than other studied composites. This is also the reason why the wear resistance of $\mathrm{NbC}$ reinforced composites decreases with increasing reinforcement content.

\section{CONCLUSIONS}

Based on the performed study it is evident that in order to improve the abrasive wear resistance of the tool steel by adding hard particles, the matrixparticle interface should be strong enough to prevent the detachment of particles and the amount of particles should be high enough to compensate the accelerated wear of the matrix because of the hard particle wear debris. Also the reinforcement material should be without internal faults and have a good wear resistance against abrasion.

\section{ACKNOWLEDGEMENTS}

Sanna Ala-Kleme would like to thank the Graduate School on New Materials and Processes for support. The authors are also grateful to P. Korpiala, S. Siipilehto and T. Seppälä for their assistance during this work. 


\title{
REFERENCES
}

1. Lindroos, V., Hellman, J., Lou, D., Nowak, R., Pagounis, E., Liu, X. W. and Penttinen, L. Designing with metal-matrix composites. In Handbook of Mechanical Alloy Design (Totten, G., Xie, L. and Funatani, K., eds.). Marcel Dekker, New York, 2003.

2. Lou, D., Hellman, J., Luhulima, D., Liimatainen, J. and Lindroos, V. K. Interactions between tungsten carbide (WC) particulates and metal matrix in WC-reinforced composites. Mater. Sci. Eng., 2003, A340, 155-162.

3. Berns, H. Comparison of wear resistant MMC and white cast iron. Wear, 2003, 254, 47-54.

4. Pagounis, E., Talvitie, M. and Lindroos, V. K. Influence of reinforcement volume fraction and size on the microstructure and abrasion wear resistance of hot isostatic pressed white iron matrix composites. Metall. Mater. Trans., 1996, 27A, 4171-4181.

5. Zum Gahr, K. H. Microstructure and Wear of Materials. Tribology series, 10. Elsevier, Amsterdam, 1987.

6. Colaco, R. and Vilar, R. A model for the abrasive wear of metallic matrix particle-reinforced materials. Wear, 2003, 254, 625-634.

7. Ala-Kleme, S., Hellman, J., Liimatainen, J. and Hannula, S.-P. Abrasion resistance of WC-Co reinforced steel matrix composites. In Proc. Twelfth International Conference on Composites/Nano Engineering, ICCE-12. Tenerife, 2005, CD.

8. Pagounis, E., Talvitie, M. and Lindroos, V. K. Microstructure and mechanical properties of hot work tool steel matrix composites produced by hot isostatic pressing. Powder Metall., 1997, 40, 55-61.

9. Pagounis, E. and Lindroos, V. K. Processing and properties of particulate reinforced steel matrix composites. Mater. Sci. Eng., 1998, A246, 221-234.

10. Pagounis, E., Talvitie, M. and Lindroos, V. K. Consolidation behavior of a particle reinforced metal matrix composite during HIPing. Mater. Res. Bull., 1996, 31, 1277-1285.

11. Kivikytö-Reponen, P., Liimatainen, J., Hellman, J. and Hannula, S.-P. Correlation between metal matrix composite structure and abrasive wear performance in mineral crushing. In Proc. Twelfth International Conference on Composites/Nano Engineering, ICCE-12. Tenerife, 2005, CD.

\section{Kuumisostaatpressimisel saadud maatriksmetall- komposiitide omadused abrasiivsel erosioonil}

\author{
Sanna Ala-Kleme, Päivi Kivikytö-Reponen, Jari Liimatainen, \\ Jussi Hellman ja Simo-Pekka Hannula
}

Tänu kõrgele kulumiskindlusele on terasmaatrikskomposiidid atraktiivsed materjalid paberi- ja tselluloositööstuses ning maakide peenestamisel. Artiklis on uuritud tööriistaterasmaatriksiga komposiitide omadusi abrasiivkulumise tingimustes. Katsed on läbi viidud kuue erineva komposiidiga pöörleva kummikettaga tekitatud abrasiooni korral. Maatriksmaterjalina on kõikide komposiitide puhul kasutusel tööriistateras Ralloy ${ }^{\circledR}$ WR6. Tavaliselt on maatriksis enne sarrusosakeste lisamist ligikaudu 20 mahuprotsenti vanaadiumkarbiidi. Sarrusena on kasutusel kas kõvasulam (WC-Co), valuvolframkarbiid (WC) või nioobiumkarbiid (NbC). Kõik materjalid on kaksikdispersioonkomposiidid, omades kahte erinevat sarruse liiki. Ehkki on leitud, et sarruselementide lisanditega komposiitmaterjalide kulumiskindlus suureneb kivipurustites mitmete kulumisliikide ühe- 
aegsel toimel, on puhta abrasiooni kindlus juhul, kui sarruselementide osa ületab $30 \%$, halvem kui maatrikstööriistaterasel. On kindlaks tehtud, et tööriistateraste kulumiskindluse tõstmisel kõvade osakeste lisamisega peab matriitsi ja osakeste vaheline side olema piisavalt tugev, et vältida osakeste eraldumist, ja osakeste kogus küllalt suur, et kompenseerida matriitsi suuremat kulumist kõvade osakeste väljalangemise tõttu. 